\title{
INFORMATION AND NEWS
}

\section{0th Anniversary of Professor Ilmar Talve's (1919-2007) Birth Hanneleena Hieta \& Helena Ruotsala}

At the beginning of the 1990s, when the map of Europe was being drawn again, things became interesting at the Department of Ethnology at the University of Turku. Professor emeritus Ilmar Talve (retired in 1986) followed the events in his native Estonia in real time. After listening to the Estonian news through the previous night and morning, Talve gave his report during the afternoon coffee hour.

These expatriate Estonian reports continued until Estonia regained its independence, after which professor Talve was able to visit his native country, which he had left behind in 1944 . He had promised to travel to Estonia only after it was independent again. In the autumn of 1991, he travelled to independent Estonia, and the journey was documented for television by journalist Jari Hakkarainen, an ethnology graduate. The document can be viewed at the YLE Elävä arkisto service (https://areena.yle.fi/1-4348051).

The year 2019 marks the 100th anniversary of professor Ilmar Talve's birth. The first Professor of Ethnology at the University of Turku, native Estonian, Ilmar Talve's scientific and literary career has been important but his input in ethnology has not been analysed to a larger degree. The anniversary of his birth gives us an excellent opportunity to do so.

Professor Talve's life career spans from Estonia to Finland, where he accomplished a remarkable life work in the field of ethnology. His influence in ethnology and its development can still be seen, because already during his time the discipline expanded both timewise and thematically from the research of peasant culture to all strata of people and contemporary times, thus creating bases for societal ethnology.

Ethnology as a discipline was started at the University of Turku in 1958, but the chair was established a little later, in 1960. Ilmar Talve was the first professor from the establishment until 1986. According to Talve's memoirs, coming to Turku marked his arrival to his third home country, Finland. By that point, he had lived in Estonia and Sweden, where the events of world history had taken him after the Second World War.

Talve was born in Ingermanland in Mga on 17 January 1919. His parents had moved to Mga because of work, but they returned to Estonia from the turbulent circumstances in Russia in 1920. They first lived in Otepää and later in Tapa, which became important to him as the city where he received his 
schooling. Already in school, he became interested in folk tradition, and in 1938 he started his studies in ethnology, folk poetry, and Estonian language and literature at the University of Tartu. He graduated in 1942.

Already the following year, Talve fled the German army, which had taken over Estonia, to Finland, where he joined a battalion of volunteers. Talve has written about this time in his book Juhanssoni reisid (1959, in Finnish Juhanssonin matkat 1961, 1991). Later, in 1944 he returned to Estonia to relocate to Sweden. His journey there included a shipwreck that nearly cost his life, a German internment camp, Flensburg and Denmark.

Talve's students have written that it was pivotal to his scientific orientation that he was able to continue studies he had started in Tartu under the supervision of Sigurd Erixon already in 1945. In addition to his studies, Talve worked with Erixon as his leader at the Department of Folklivsforskning and the Nordic Museum in Stockholm. Professor Erixon has probably had the strongest influence on Talve's view on ethnology.

In Stockholm, Talve belonged to the expatriate Estonian cultural political circle and had a role as an important expatriate writer. He continued his literary career later in Finland.

Talve defended his doctoral dissertation on saunas and buildings for drying grain in Northern Europe (Bastu och torkhus i Nordeuropa) in Stockholm in 1960. It was based on large international comparative data. His years in Sweden had given him new ideas on ethnology and its position and importance, but in addition, also a lot of fieldwork notes and photographs. His students have made use of these in post-doctorate research, for example his fieldwork materials on Forest Finns (Sappinen, forthcoming).

At the turn of the 1950s and 1960s, the focal point of ethnology in Finland was still on the already extinct peasant culture, especially its material side, and the Finno-Ugrian viewpoint was still present in the name of the chair at the University of Helsinki, which also had an influence on the chair there. Thus, Talve's ideas about ethnology and its role that came from Sweden were both different and refreshing.

Ethnology at the University of Turku started in conjunction with sociology, and it was therefore also natural that it saw folk culture from a societal point of view. When Talve started to develop ethnology in Turku, he saw new, different focal points for research. Ethnology expanded to the areas of industrial workers and occupational groups, as well as the rural transformation that was going on during the era of industrialisation, and to urban ethnology.

All of these areas, but in particular urban ethnology and research of rural transformation play an important role in ethnology at the University of Turku 
even today, albeit with slightly different emphases and names. (See for example Fingerroos et al. 2017 with a number of contributions from ethnologists in Turku; Lehtonen 2016; Vanha-Similä 2017.)

Talve made ethnology cover all strata of Finnish folk and from the past to the present. It is interesting that research in material culture never took a strong foothold in ethnology in Turku. In addition, Talve started a largescale data collection in the form of postal questionnaires and fieldwork interviews. All data and a large photo archive are housed at the department archives (Archives of History, Culture and Arts Studies at the University of Turku). Even today, all research data generated at the department is archived there.

Ilmar Talve's scientific publication activity was exceptionally wide and varied. As a researcher, we could define him as an empiricist, whose text is based on detailed management of data. His main oeuvre Suomen kansankulttuuri was published in 1979. It has later been translated and published in English (1997) and Hungarian (2000).

After his retirement, Talve's scientific and literary career continued. His three-part autobiography was published in Estonian - Kevad Eestis (1997), Kutsumatu küliline (1998) and Kolmas kodumaa (1999) - and an abridged Finnish version was published in 2004. He also published an 800-pagelong general presentation of Estonian cultural history, Eesti Kulttuurilugu, in 2004.

Professor Talve was one of the founding members of the Association of Finnish Ethnologists, Ethnos. Ilmar Talve was married to Liisa Kervinen. They had three children. He passed away on 21 April 2007 in Turku.

The chair of Ethnology at the University of Turku - in collaboration with the Ethnos Association and Seurasaari Foundation - will arrange a seminar which, on the one hand, will analyse professor Ilmar Talve's scientific legacy from the aforementioned aspects and, on the other, create trajectories to present-day research on breaking points and processes of transformation. Of these processes of transformation, we can mention, for example, urban ethnology, consolidation of municipalities, rural transformation and corporate culture. What connects all of these is societal ethnology and its role in modern society. What has been the meaning of these to ethnology? How has our research object, the folk, changed in Finland, Estonia and Sweden? And finally, are these changes so big that, also in Finnish, we should change the name of the discipline to ethnology instead of kansatiede? What is the role of ethnology today? The call for papers for this seminar can be read at its website (http://ilmartalve100.utu.fi). 


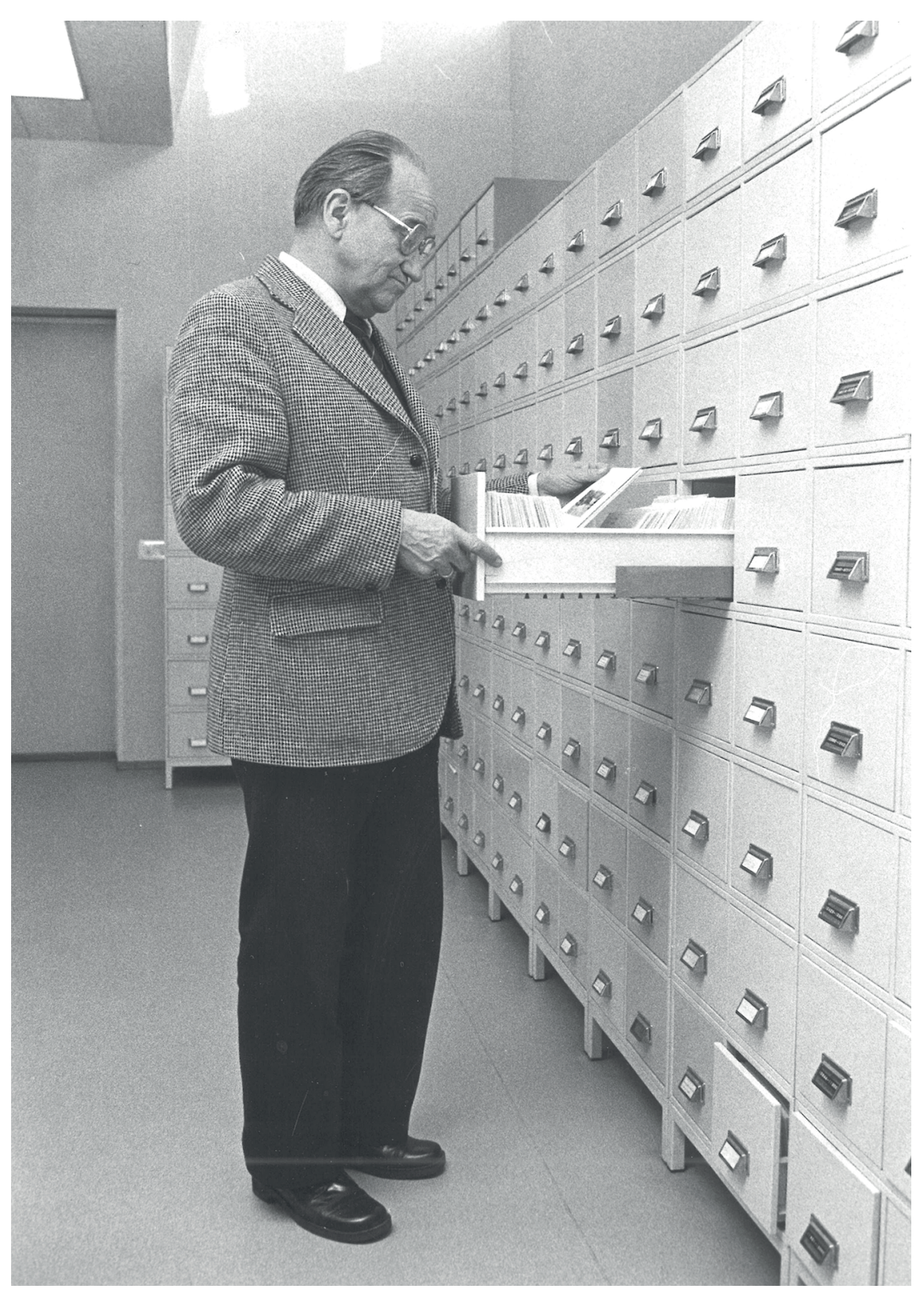

Professor IImar Talve in front of archive cabinets. Picture: Ethnology, University of Turku. 


\section{AUTHORS}

PhD Hanneleena Hieta is a postdoctoral researcher in ethnology at the University of Turku. In addition to her main topic of cultural heritage, she has done research on transnational families and Finnish-American entrepreneurs.

Helena Ruotsala, $\mathrm{PhD}$, docent, is a professor of European ethnology in the University of Turku

\section{Bibliography}

Fingerroos, Outi, Lundgren, Maija, Lillbroända-Annala, Sanna, and Koskihaara, Niina (eds). 2017. Yhteiskuntaetnologia. Helsinki: Finnish Literature Society.

Lehtonen, Jussi. 2016. Skenaarioita maaseudun palveluista. Turku: University of Turku.

Sappinen, Eero. 2010. Talve, IImar. The Kansallisbiografia website. Studia Biographica 4. Helsinki: Finnish Literature Society. Accessed October 4, 2018. https://kansallisbiografia.fi/kansallisbiografia/henkilo/8838

Sappinen, Eero. 2018. Värmlannin metsäsuomalaiset: Asutushistoriasta, agraarista kulttuurista ja muutoksesta. Turku: Migration Institute of Finland. Forthcoming.

Talve, IImar. 1959. Juhanssoni reisid. Lund.

Talve, IImar. 1960. Bastu och torkhus i Nordeuropa. Stockholm: Nordic Museum.

Talve, IImar. 1961. Juhanssonin matkat. Hämeenlinna: Karisto.

Talve, IImar. 1979. Suomen kansankulttuuri. Helsinki: Finnish Literature Society.

Talve, IImar. 1997. Kevad Eestis. Autobiograafia I. Tartu: IImamaa.

Talve, IImar. 1998. Kutsumatu külaline. Autobiograafia II. Tartu: IImamaa.

Talve, IImar. 1999. Kolmas kodumaa. Autobiograafia III. Tartu: IImamaa.

Talve, IImar. 2004. Kolme kotimaata. Turku: Kirja-Aurora.

Vanha-Similä, Marja. 2017. Yhtiöön, yhtiöön! Lapsiperheiden arki Forssan tehdasyhteisössä 1950-1970-Iuvuilla. Helsinki: Finnish Antiquarian Society.

Virtanen, Timo (ed.). 1999. IImar Talve: bibliografia 1934-1998: LXXX annorum 17.1.1999. Turku: Ethnology, University of Turku. 